\title{
Aldo Hermawan
}

\section{5 / KP A}

\section{MICRO AND SMALL BUSSINESS IN INDONESIA DIGITAL ECONOMY}

Micro and small and medium enterprises (MSMEs) account for around 99 per cent of existing business enterprises in Indonesia and employ more than 95 per cent of the total workforce across the country. These businesses should be the primary engines of economic growth. But they generate only around 56 per cent of the GDP in Indonesia1. The United Nations defines a micro-enterprise as having fewer than 10 employees; small businesses as having fewer than 50 employees; and medium sized businesses, fewer than 250 employees. In Indonesia, the majority of businesses are micro enterprises. Indonesian MSMEs historically have been excluded from regional and global value chains - and even marginalized within local markets - due to a lack of connectivity with markets, access to finance and knowledge networks and a dearth of human capital (the right skill sets), particularly when it comes to the fundamentals of starting and running a successful digital business.

Today, the harnessing of digital technology combined with proactive policymaking has the potential to empower MSMEs and "level them up" into new value chains. Policy-makers in Jakarta and stakeholders throughout the country have recognized this. In 2016, Indonesian President Joko Widodo launched a technology development plan to make Indonesia the largest digital economy in Asia by 2020, with a target of US $\$ 130$ billion in digital revenues2. As part of this initiative, the Gerakan Nasional 1000 Startup Digital Initiative was launched and has made tremendous progress3. Investment in Indonesian startups in 2016 reached US\$1.4 billion and then jumped to US\$3 Billion in the first eight months of 20174. In 2017, Indonesia's Commission for the Supervision of Business Competition (KPPU) issued a report that concluded that 3.7 million new jobs would be created within the digital economy by 20255 and that MSMEs could leverage technology to achieve an 80 per cent increase in revenue growth.

Technology is creating new opportunities and lowering barriers to entry for MSMEs. The digital platform economy is enabling the development of human capital by connecting small enterprises to the digital global commons. This means access to new markets and resources such as cloud-based tools, e-commerce platforms, and mobile apps that can facilitate an infinite amount of economic and social activities. According to Statistica, smart phone penetration in Indonesia has reached 43.2 per cent of its population and is rising rapidly. Indonesians spend an average of eight hours and 51 minutes per day on the Internet and the country is currently ranked fourth in the world in this category, behind Thailand, the Philippines and Brazil7. In this regard, digital technology should be regarded as a power multiplier or a "levelling up" mechanism for MSMEs. This should be viewed positively by policymakers, particularly as governments in emerging markets are striving to embrace strategies that create an environment of "inclusive capitalism" for small business owners. Digital mobile technology is fuelling growth of the informal economy which presents regulatory challenges to Indonesian policy-makers as well as depriving the government of valuable tax revenues. According to a report by the Foundation for Economic Education, as much as 60 per cent of Indonesia's economy is already in the informal sector8. There are caveats associated with these new technologies, primarily when it comes to the role that large platform companies play in the growth of the digital economy. Facebook, Twitter, YouTube, and Instagram, for example, have an overwhelming - some would say oligopolistic - presence in Indonesia and these firms have been accused of crowding out local players.

Large foreign tech companies have been investing heavily in Indonesia's digital landscape. For example, Tokopedia, one of Indonesia's largest e-commerce platforms, recently secured US\$1.1 billion from 
China's Alibaba investor group $\square$. Similarly, Go-Jek, Indonesia's first unicorn — a privately held start-up company valued at more than US\$1 billion - has been rapidly diversifying its revenue stream from ridesharing to digital payment and last mile logistics apps and has relied on Chinese tech giants Tencent Holdings Ltd. and JD.com Inc. to secure crucial funding. Most recently, Google, Singapore's Temasek Holdings and China's Meituan Dainping teamed up for a \$1.2-billion fundraising campaign on behalf of Go-jek, which also included investment firms KKR and Warburg Pincus.

The presence of the world's largest tech firms in Indonesia's digital economy present both tremendous opportunities and challenges for Indonesian MSMEs. Indonesia's policy-makers will have to strike a balance between embracing foreign investment, while at the same time creating a business environment that nurtures the development of local firms in a fair and open digital market place. But the challenges posed by large foreign tech giants in Indonesia's emerging digital economy is not the focus of this report. That is a topic that needs to be addressed in a separate study. The focus of this report is the positive impact that technology can play to integrate MSMEs into markets, and, most importantly, how to develop and promote human capital through training programs and partnerships to maximize the economic participation of MSMEs in local, regional, and even global value chains. 